\title{
Cellular prion protein mediates early apoptotic proteome alternation and phospho-modification in human neuroblastoma cells
}

\author{
Saima Zafar ${ }^{1}$, Christina Behrens ${ }^{2}$, Hassan Dihazi ${ }^{3}$, Matthias Schmitz ${ }^{1}$, Inga Zerr ${ }^{1}$, Walter J Schulz-Schaeffer ${ }^{2}$, Sanja Ramljak ${ }^{\star, 4,6}$ and
} Abdul R Asif ${ }^{*, 5,6}$

Anti-apoptotic properties of physiological and elevated levels of the cellular prion protein ( $\mathrm{PrP}^{\mathrm{c}}$ ) under stress conditions are well documented. Yet, detrimental effects of elevated $\mathrm{PrP}^{\mathrm{C}}$ levels under stress conditions, such as exposure to staurosporine (STS) have also been described. In the present study, we focused on discerning early apoptotic STS-induced proteome and phosphoproteome changes in SH-SY5Y human neuroblastoma cells stably transfected either with an empty or PRNP-containing vector, expressing physiological or supraphysiological levels of $\mathrm{PrP}^{\mathrm{c}}$, respectively. $\mathrm{PrP}^{\mathrm{c}}$-overexpression per se appears to stress the cells under STS-free conditions as indicated by diminished cell viability of $\mathrm{PrP}^{\mathrm{C}}$-overexpressing versus control cells. However, $\mathrm{PrP}^{\mathrm{C}}$ overexpression becomes advantageous following exposure to STS. Thus, only a short exposure $(2 \mathrm{~h})$ to $1 \mu \mathrm{M}$ STS results in lower survival rates and significantly higher caspase-3 activity in control versus $\mathrm{PrP}^{\mathrm{C}}$-overexpressing cells. Hence, by exposing both experimental groups to the same apoptotic conditions we were able to induce apoptosis in control, but not in PrPc ${ }^{c}$-overexpressing cells (as assessed by caspase-3 activity), which allowed for filtering out proteins possibly contributing to protection against STSinduced apoptosis in $\mathrm{PrP}^{\mathrm{C}}$-overexpressing cells. Among other proteins regulated by different $\mathrm{PrP}^{\mathrm{C}}$ levels following exposure to STS, those involved in maintenance of cytoskeleton integrity caught our attention. In particular, the finding that elevated PrP ${ }^{\mathrm{C}}$ levels significantly reduce profilin-1 (PFN-1) expression. PFN-1 is known to facilitate STS-induced apoptosis. Silencing of PFN-1 expression by siRNA significantly increased viability of $\mathrm{PrP}^{\mathrm{C}}$-overexpressing versus control cells, under STS treatment. In addition, PrPc-overexpressing cells depleted of PFN-1 exhibited increased viability versus PrPc ${ }^{\mathrm{c}}$-overexpressing cells with preserved PFN-1 expression, both subjected to STS. Concomitant increase in caspase-3 activity was observed in control versus PrPc-overexpressing cells after treatment with siRNA- PFN-1 and STS. We suggest that reduction of PFN-1 expression by elevated levels of PrPc may contribute to protective effects PrPc ${ }^{\mathrm{C}}$-overexpressing SH-SY5Y cells confer against STS-induced apoptosis.

Cell Death and Disease (2017) 8, e2557; doi:10.1038/cddis.2016.384; published online 19 January 2017

Apoptosis is essential for maintenance of cellular homeostasis as a part of normal development of the nervous system. ${ }^{1}$ At the same time apoptosis is also a characteristic of many neurodegenerative disorders. ${ }^{2}$ Furthermore, reduced apoptotic cell death or its obstruction is one of the critical cellular changes during malignant transformation. ${ }^{3}$

Considering that cellular prion protein $\left(\mathrm{PrP}^{\mathrm{C}}\right)$ is necessary for propagation of prion diseases and that apoptosis has been described in the brains of patients affected by these diseases, ${ }^{4}$ a more complete understanding of $\mathrm{PrP}^{\mathrm{c}}$ impact on apoptotic cell death is required. Moreover, $\mathrm{PrP}^{\mathrm{C}}$ appears to be involved in the pathogenesis of Alzheimer disease ${ }^{5}$ and in promoting invasiveness of different cancer cell types, ${ }^{6,7}$ both of which are accompanied by dysregulated apoptosis. ${ }^{3,8}$

Although expression of $\mathrm{PrP}^{\mathrm{c}}$ at physiological levels is known to exert protective, anti-apoptotic effects in vitro as well as in vivo, ${ }^{9-11}$ other evidence strongly suggest that $\mathrm{PrP}^{\mathrm{c}}$ overexpression in different cell lines sensitises cells to apoptotic stimuli. ${ }^{12,13}$ It appears that an augmented susceptibility to apoptotic stimuli, such as staurosporine (STS), is governed by a p53-dependent pathway. Moreover, in vivo findings demonstrated that $\mathrm{PrP}^{\mathrm{c}}$ overexpression can induce spontaneous neurodegeneration, ${ }^{14,15}$ and that local $\mathrm{PrP}^{\mathrm{c}}$ overexpression in muscles leads to primary myopathy, most likely via a p53 pathway. ${ }^{16}$ Earlier, we reported disturbed cellular homeostasis following $\mathrm{PrP}^{\mathrm{C}}$ overexpression in human neuroblastoma SH-SY5Y cells, but were unable to show that a sole overexpression of $\mathrm{PrP}^{\mathrm{C}}$ can alter p53 levels. ${ }^{17}$

Yet, another study employing mouse neuroblastoma N2a cell line suggested that physiological levels of $\mathrm{PrP}^{\mathrm{c}}$ have a decisive protective role against STS-mediated cell death. ${ }^{18}$

Keeping in mind that elevated $\mathrm{PrP}^{\mathrm{C}}$ levels per se may provoke neurodegeneration, ${ }^{14}$ that neurodegenerative diseases, including prion diseases are characterized by neuronal

\footnotetext{
${ }^{1}$ Department of Neurology, Georg-August University, Goettingen 37075, Germany; ${ }^{2}$ Department of Neuropathology, Georg-August University, Goettingen 37075 , Germany; ${ }^{3}$ Department of Nephrology and Rheumatology, Georg-August University, Goettingen 37075, Germany; ${ }^{4}$ Sciema UG, An der Hayl 4, Mainz 55130, Germany and ${ }^{5}$ Institute for Clinical Chemistry / UMG-Laboratories, University Medical Center Goettingen, Georg-August University, Goettingen, Germany

*Corresponding author: S Ramljak, Sciema UG, An der Hayl 4, Mainz 55130, Germany. Tel: +49 (6131) 63-68624; Fax: +49 (6131) 63-68627;

E-mail: sanja.ramljak@sciema.de

or AR Asif, Institute for Clinical Chemistry/UMG-Laboratories, University Medical Center Goettingen, Georg-August University, Goettingen 37075 Germany. Tel: +49 (551) 39-22945; Fax: +49 (551) 3912505; E-mail: asif@med.uni-goettingen.de

${ }^{6}$ These authors contributed equally to this work.

Received 31.5.16; revised 05.10.16; accepted 05.10.16; Edited by A Stephanou
} 
apoptosis, ${ }^{19,20}$ and that rise in $\mathrm{PrP}^{\mathrm{c}}$ expression promotes invasiveness and survival of cancer cells, ${ }^{6,7}$ the aforementioned conflicting findings on $\mathrm{PrP}^{\mathrm{C}}$ expression levels and its associated pro- and/or anti-apoptotic properties should be further elucidated.

This study aimed at revealing largely unknown proteome and phospho-proteome changes of early apoptotic events following treatment of human neuroblastoma SH-SY5Y control cells, stably overexpressing an empty vector, with apoptotic agent STS versus SH-SY5Y cells stably overexpressing $\mathrm{PrP}^{\mathrm{C}}$ exposed to the same apoptotic agent.

STS is a non-selective protein kinase inhibitor that has been extensively used as one of the most potent pro-apoptotic stimuli in a variety of cells. ${ }^{21-23}$ Although molecular mechanisms of STS-induced apoptosis are still not completely clear an involvement of caspase activation ${ }^{24}$ is certain.

By identifying early changes in protein expression patterns between physiological and $\mathrm{PrP}^{\mathrm{C}}$ overexpressing levels, on 'the edge of apoptosis' (already present in control, but not in $\mathrm{PrP}^{\mathrm{C}}$ overexpressing cells, as assessed by caspase-3 activation) we aimed at filtering out proteins contributing to previously observed expression level-mediated pro- and/or anti-apoptotic $\mathrm{PrP}^{\mathrm{C}}$ properties. Identification of these candidate proteins might improve our understanding of $\mathrm{PrP}^{\mathrm{c}}$ function both in health and disease.

\section{Results}

To identify early apoptotic changes following 2-h exposure to $1 \mu \mathrm{M}$ STS a quantitative proteome and phospho-proteome analysis was performed using human neuroblastoma SH-SY5Y cells stably transfected either with PRNP or an empty vector, respectively. An introduction of $\mathrm{pCIneoPRNP}$ plasmid into SH-SY5Y cells treated with either DMSO or STS resulted in an average 5- $\left(P=3.7 \times 10^{-5}\right)$ to 7 -fold $\left(P=6.5 \times 10^{-4}\right)$ higher expression of $\mathrm{PrP}^{\mathrm{C}}$ in $\mathrm{PrP}^{\mathrm{C}}$-overexpressing (designated $\mathrm{PrP}$ ) versus control SH-SY5Y cells (designated ctrl), as quantified by ELISA measurements (Figure 1). Remarkably, PrP cells demonstrated diminished viability in MTS assay as compared with control cells, both under treatment-free conditions $\left(P=1 \times 10^{-5}\right)$ and following DMSO treatment $\left(P=6.5 \times 10^{-5}\right)$. After STS treatment an increased viability rates of PrP versus control cells were observed $(P=0.019)$ (Figure 2a). Concomitantly, caspase-3 activity, a marker of programmed cell death, was significantly $(P=0.017)$ increased in control as compared with PrP cells, both subjected to STS treatment (Figure 2b).

Densitometric analysis of silver-stained 2-DE gels revealed altogether 14 (Table 1), whereas phospho-protein staining revealed 10 (Table 2) differentially expressed proteins (Figures 3 and 4) across all compared experimental groups. To be able to differentiate between protein expression changes induced by either STS or the solvent (DMSO) six different experimental groups were compared (Tables 1 and 2).

The threshold for identification of up-/down-regulated proteins was set to 1.5- (proteome) and 1.4-fold (phosphoproteome) changes, respectively. Based on this criterion, we detected 11 up- and 10 down-regulated proteins (five distinct proteins were repeatedly found to be differentially regulated across different transfection/treatment groups) following silver staining of 2-DE gels throughout all experimental groups.

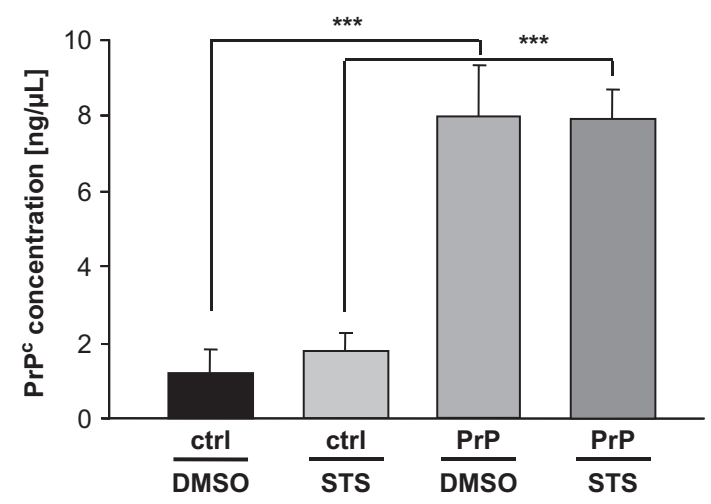

Figure 1 ELISA analysis of $\mathrm{PrP}^{\mathrm{C}}$ levels in parental and SH-SY5Y cells stably transfected with $\mathrm{pC}$ IneoPRNP vector following DMSO/STS treatment. PrP ${ }^{\mathrm{C}}$ levels were analyzed following treatment of parental (expressing endogenous PrPc; designated ctrl) and PrPC-overexpressing (designated PrP) SH-SY5Y cells with either DMSO or $1 \mu \mathrm{M}$ STS for $2 \mathrm{~h}$. Note markedly, 7 -and 5 -fold, higher PrPC expression in pCIneoPRNP transfected versus parental cells following DMSO and STS treatment, respectively. $\mathrm{PrP}^{\mathrm{C}}$ concentration was measured in $50 \mu \mathrm{g}$ of proteins. Values represent the mean \pm S.D. of four independent experiments (two-sided unpaired Student's $t$-test $\left.{ }^{* \star *} P \leqslant 0.001\right)$

Exemplarily, actin-interacting protein 1 was detected as differentially regulated in $\mathrm{PrP}^{+\mathrm{STS}} / \mathrm{ctrl}^{+\mathrm{STS}}$ and $\mathrm{PrP}^{+\mathrm{STS}}$ / $\mathrm{ctrl}^{+\mathrm{DMSO}}$ group. Seven proteins exhibited a 2-fold or higher regulation after silver staining of 2-DE (Table 1). Two experimental groups: $\mathrm{PrP}^{+\mathrm{DMSO}} / \mathrm{ctrl}^{+\mathrm{STS}}$ and $\mathrm{PrP}^{+\mathrm{STS}} / \mathrm{ctrl}^{+\mathrm{DMSO}}$ did not demonstrate any differentially regulated proteins following silver staining.

According to above mentioned criterion, we detected 4 upand 7 down-regulated phosphorylated proteins throughout all experimental groups. Altogether, a majority of differentially expressed proteins (45.5\%) appertains to a protein metabolism/folding group of proteins, $22.7 \%$ to energy metabolism, $18.2 \%$ of proteins belong to cytoskeleton group of proteins and finally $13.6 \%$ to stress response group (Figure 5).

Owing to the emerging role of $\mathrm{PrP}^{\mathrm{c}}$ in maintenance of cytoskeleton organization, ${ }^{25}$ we decided to analyse expression level of two differentially regulated cytoskeletal proteins, PFN-1 and transgelin-2 using western blot analysis (Figure 6). Profilin-1 protein expression was 1.64-fold $(P=0.042)$ lower in $\mathrm{PrP}^{+\mathrm{STS}}$ versus $\mathrm{ctrl}^{+\mathrm{STS}}$ group with a score of 627 , whereas trangelin-2 expression was 3.65 -fold $(P=0.008)$ higher in $\mathrm{PrP}^{+\mathrm{STS}}$ as compared with $\mathrm{ctrl}^{+\mathrm{STS}}$ group with a score of 393 (Table 1). Densitometric analysis of western blot protein bands revealed $\sim 1.5$-fold lower expression of Pfn1 in $\mathrm{PrP}^{+\mathrm{STS}}$ as compared with $\mathrm{ctrl}^{+S T S}$ group $(P=0.021)$. Nearly the same ratio of differential expression (1.5-fold) was retained between all the other groups compared, with the following levels of significance: ctrl $^{+\mathrm{DMSO}}$ versus $\mathrm{ctrl}^{+\mathrm{STS}}(P=0.001) ; \mathrm{PrP}^{+\mathrm{DMSO}}$ versus $\mathrm{PrP}^{+\mathrm{STS}}(P=0.046)$ and ctrl $^{+\mathrm{DMSO}}$ versus $\mathrm{PrP}^{+\mathrm{DMSO}}$ $(P=0.0002)$. A significant elevation of transgelin-1 expression is observed in $\mathrm{PrP}^{+\mathrm{STS}}$ group as compared with all three other groups $(P=0.0003)$. Intriguingly, p53 expression pattern is analogues to that of Pfn1 (Figure 6a). Although not detected as regulated in densitometric analysis of 2-DE gels, we decided to check p53 expression levels between different experimental groups because of previously reported involvement of this protein in the exertion of $\mathrm{PrP}^{\mathrm{c}}$ function when 

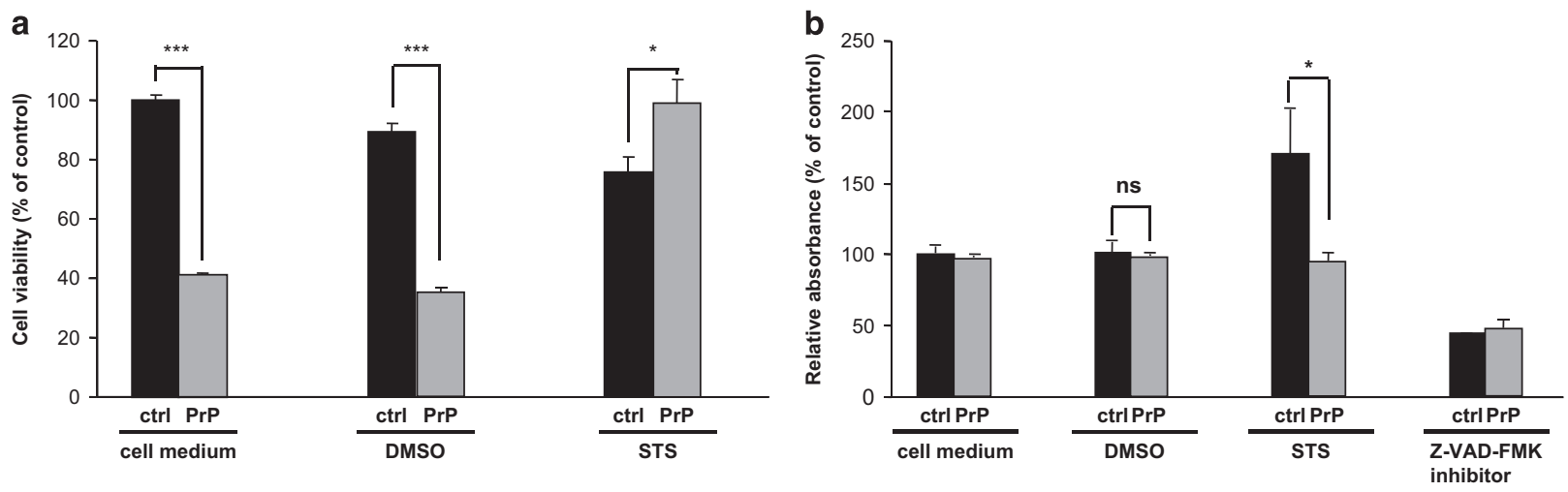

Figure 2 Cell viability (a) and caspase-3 activity (b) in empty vector transfected and PrPc-overexpressing SH-SY5Y cells subjected to apoptotic agent STS. SH-SY5Y cells expressing either endogenous $\mathrm{PrP}^{\mathrm{c}}$ (designated ctr//black bars) or overexpressing $\mathrm{PrP}^{\mathrm{C}}$ (designated PrP/grey bars) were subjected to DMSO (vehicle control) or $1 \mu \mathrm{M}$ STS treatment for $2 \mathrm{~h}$. As a negative control both, ctrl and PrP SH-SY5Y cells were incubated in the cell medium only, without addition of DMSO or STS. During performance of caspase assay a potent caspase-3 activity inhibitor (Z-VAD-FMK) was used as a positive control. Note, a significantly lower cell viability in PrP as compared with control cells under both, treatment-free (cell medium) and DMSO treatment conditions with no obvious changes in caspase-3 activity (ns). Conversely, after STS treatment a survival rate of $\mathrm{PrP}^{\mathrm{C}}$-overexpressing cells was significantly higher as compared with cells expressing endogenous levels of $\mathrm{PrP}^{\mathrm{C}}$. At the same time STS treatment resulted in caspase-3 activity in control, but not in PrP cells. Cell viability and caspase-3 activity were expressed as a percent of relative absorbance to untreated control cells expressing endogenous level of $P_{P} P^{c}$. Data are means \pm S.D. of duplicate measurements from four independent experiments. Level of significance was calculated using Student's $t$-test: ${ }^{*} P \leqslant 0.05 ;{ }^{* \star *} P \leqslant 0.001$

challenged with STS. ${ }^{26}$ Indeed, expression of p53 was 1.4-fold higher in $\mathrm{ctrl}^{+\mathrm{STS}}$ versus $\mathrm{PrP}^{+\mathrm{STS}}$ group $(P=0.0003)$. Ctrl ${ }^{+\mathrm{STS}}$ group showed 2.3-fold increase in 153 expression as compared with $\mathrm{ctrl}^{+\mathrm{DMSO}}$ group $(P=0.0005)$ and 3.9 -fold increase in $\mathrm{PrP}^{+\mathrm{STS}}$ versus $\mathrm{PrP}^{+\mathrm{DMSO}}$ group $\left(P=7.2 \times 10^{-5}\right)$. Finally, a 2.3fold decrease in $\mathrm{p} 53$ expression was observed in $\mathrm{PrP}^{+\mathrm{DMSO}}$ as compared with $\mathrm{ctrl}^{+\mathrm{DMSO}}$ group $(P=0.010)$.

Owing to the fact that PFN-1 promotes STS-induced apoptosis, ${ }^{27}$ and elevated levels of $\mathrm{PrP}^{\mathrm{C}}$ downregulate its expression in SH-SY5Y cells, we decided to examine the link between $\mathrm{PrP}^{\mathrm{C}}$ and PFN-1 further.

Immunofluorescence analysis additionally verified $\mathrm{PrP}^{\mathrm{C}}$ mediated expressional regulation of PFN-1 as well as its altered co-localization pattern in ctrl $^{+ \text {STS }}$ versus $\mathrm{PrP}^{+\mathrm{STS}}$ group (Figure 7).

To test if farther downregulation of PFN-1 has an effect on cell viability and caspase-3 activity of PrP versus ctrl cells treated with STS, we performed PFN-1 gene expression silencing using siRNA approach. Western blot analysis demonstrated comparable PFN-1 protein expression pattern after transfection with non-targeting mock control as obtained previously for siRNA-untreated cells (comparison between Figures $8 \mathrm{a}$ and $6 \mathrm{a}$ ). We also verified that level of $\mathrm{PrP}^{\mathrm{C}}$ overexpression following treatment with siRNA remained unchanged (data not shown). In cells transfected with siRNA-PFN-1, no protein bands neither in ctrl nor in PrP cells were visible (Figure 8a). Cell viability of PrP cells treated with siRNA-PFN-1 versus ctrl cells treated with siRNA-PFN-1 both exposed to STS was significantly increased $(P=0.0006)$, whereas caspase-3 activity was decreased $(P=0.0216)$. In addition, PrP cells treated with siRNA-PFN-1 exhibited significantly higher survival rates $(P=0.0139)$ and slightly decreased caspase- 3 activity $(P=0.0311)$ versus PrP cells treated with mock control, both subjected to STS (Figure $8 \mathrm{~b}$ and c). Remarkably, ctrl cells treated with siRNA-PFN-1 demonstrated lower survival rates $(P=0.0022)$ as compared with ctrl cells treated with mock control, both subjected to STS (Figure 8b).

\section{Discussion}

Former reports on $\mathrm{PrP}^{\mathrm{C}}$ overexpression in different experimental models remain controversial. Wild-type $\operatorname{PrP}^{\mathrm{C}}$-overexpression can either exert protective effects as shown in BAX and TNF- $\alpha$-mediated cell death in vitro ${ }^{28,29}$ or can induce neurodegeneration and primary myopathy in vivo. ${ }^{14,16}$ Several earlier studies investigating pro- and anti-apoptotic features of $\operatorname{PrP}^{\mathrm{c}}$, using STS as an apoptotic agent, found that PrP' overexpression renders cells more susceptible to apoptotic cell death, whereas cells devoid of $\operatorname{PrP}^{\mathrm{C}}$ expression demonstrate reduced susceptibility to STS-induced apoptosis. The mechanism of STS-induced $\mathrm{PrP}^{\mathrm{C}}$-regulated cell death appears to be p53-dependent and to involve capase-3 activation. ${ }^{12,13,26}$ However, the possibility that mechanism of action vary dependent on different cell types and STS concentrations used still persists. ${ }^{30}$ Hence, findings on mouse neuroblastoma N2a cell line showed that downregulation of $\mathrm{PrP}^{\mathrm{C}}$ sensitizes cells to STS-induced cytotoxicity and apoptosis, whereas an overexpression of $\mathrm{PrP}^{\mathrm{C}}$ has little or no effect. ${ }^{18}$ Interestingly, in the present study cell viability of $\mathrm{PrP}^{\mathrm{C}}$ overexpressing cells under both control (cell medium) and DMSO conditions was significantly diminished as compared with SH-SY5Y cells expressing endogenous levels of PrPc. However, after exposure to stress conditions (STS treatment) $\mathrm{PrP}^{\mathrm{C}}$-overexpression seemed to become advantageous and cell survival rates were even higher than in the control group.

The study target was to display early apoptotic proteome and phospho-proteome changes. The functional roles of identified proteins indicate that most STS-provoked apoptotic changes are linked to protein metabolism/folding, energy metabolism, stress response and cytoskeleton organization. 


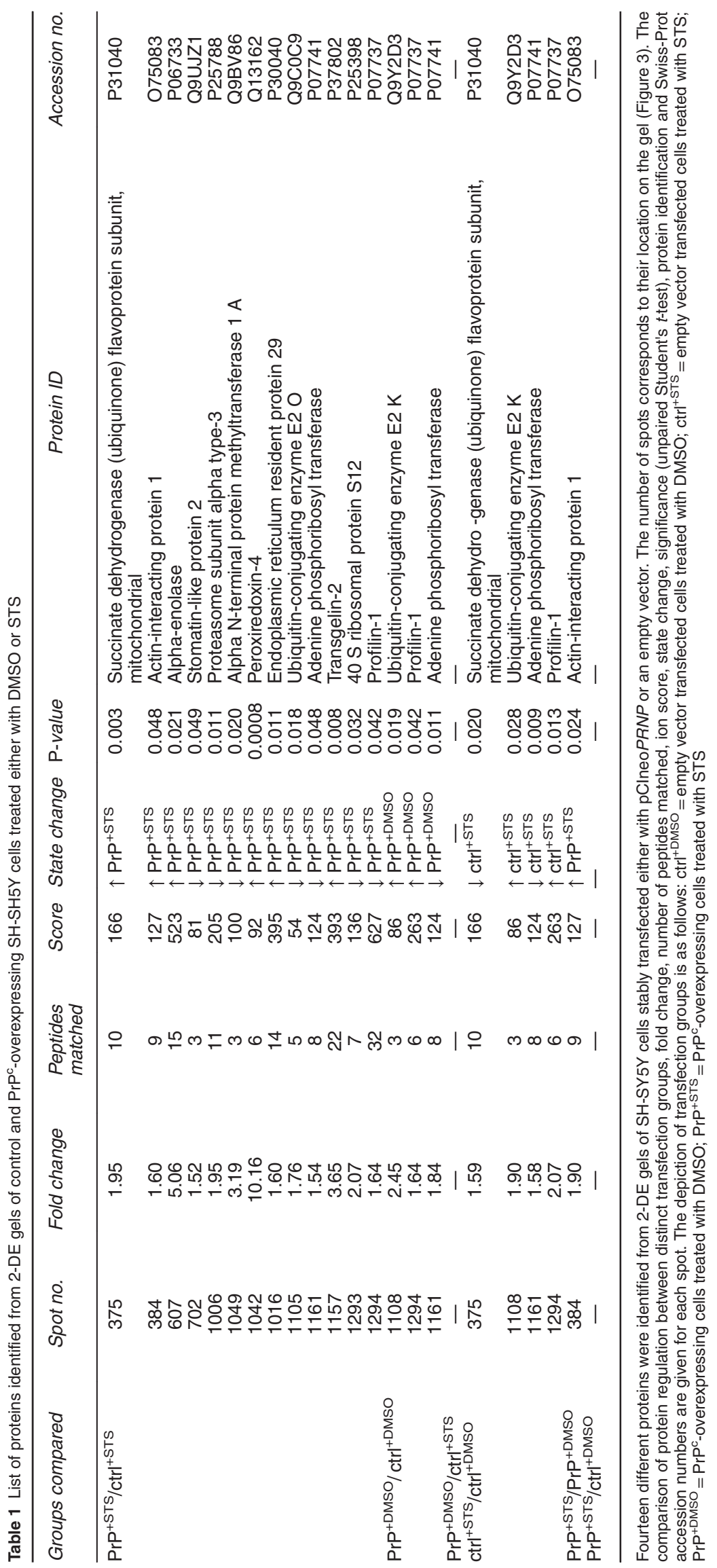




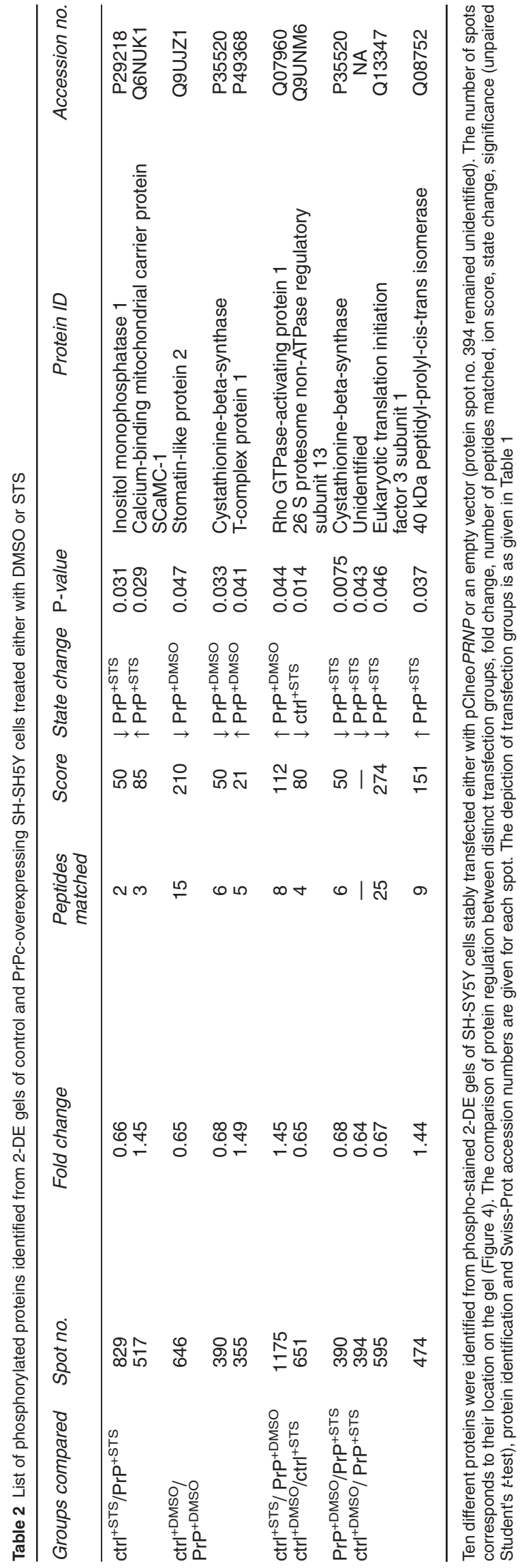

Protein metabolism/folding functional group exhibited the most protein expression/phosphorylation changes following $\mathrm{PrP}^{\mathrm{C}}$-overexpression in $\mathrm{SH}-\mathrm{SY} 5 \mathrm{Y}$ cells under employed experimental conditions. For instance, endoplasmic reticulum (ER) stress-activated protein, ER-resident protein 29, a chaperone that facilitates protein processing and transport, ${ }^{31}$ and appears to possess anti-apoptotic properties, ${ }^{32}$ demonstrated an increased expression in $\mathrm{PrP}^{\mathrm{C}}$-overexpressing versus control cells (both treated with STS). In earlier proteomic study, STS treatment of SH-SY5Y cells induced significant changes in endoplasmic reticulum proteins. ${ }^{33}$

A glycolytic enzyme, alpha-enolase, which belongs to energy metabolism functional group of proteins, demonstrated a 5-fold increase in its expression following STS treatment in $\mathrm{PrP}^{\mathrm{C}}$-overexpressing as compared with control cells underlining the ability of $\operatorname{PrP}^{c}$ to attune energy metabolism according to the physiological demands. The expression of this enzyme was clearly enhanced in a study investigating proteome changes in N2a cells after infection with $22 \mathrm{~L}$ prion strain. ${ }^{34}$

A cytoskeleton protein that showed significant changes between control and $\mathrm{PrP}^{\mathrm{C}}$-overexpressing cells after STS treatment was profilin-1 (PFN-1). This protein is ubiquitously expressed actin-binding protein, which when overexpressed facilitates STS-induced apoptosis. ${ }^{27}$ It is well-established that actin-binding proteins are of utmost importance for the adhesion of cells to extracellular matrices (ECM) and for cell survival because of their role in linkage of integrins to actin cytoskeleton. ${ }^{35}$ The fact that apoptotic cells display an early detachment from ECM and the rearrangements of actin cytoskeleton, ${ }^{36}$ an elevated expression of PFN-1 in control as compared with $\mathrm{PrP}^{\mathrm{C}}$-overexpressing $\mathrm{SH}-\mathrm{SY} 5 \mathrm{Y}$ cells, both subjected to STS, might indicate an increased susceptibility of the former group to STS-mediated apoptotic cell death. In addition, control versus $\mathrm{PrP}^{\mathrm{C}}$-overexpressing $\mathrm{SH}-\mathrm{SY} 5 \mathrm{Y}$ cells subjected to DMSO showed likewise significantly higher expression of PFN-1. It appears that STS treatment itself is sufficient to up-regulate PFN-1 expression, whereas $\mathrm{PrP}^{\mathrm{C}}$ overexpression seems to be able to decrease it. Of interest, $\mathrm{N}$-terminal sequence of $\mathrm{PrP}^{\mathrm{C}}$ possesses extended poly- $(\mathrm{L}$ proline) II (PPII) helix ${ }^{37}$ and profilin family is known to bind to polyproline binding sites. ${ }^{38}$ Profilin-1 interactions with actin and polyproline ligands advance actin polymerization and cell motility, ${ }^{39}$ which becomes important during tumor progression. Hence, downregulation of PFN-1 was reported in different adenocarcinoma (i.e., breast, pancreatic). ${ }^{40,41}$ Loss of PFN-1 expression led to increased motility and invasiveness of MDAMB-231 breast cancer cells, whereas PFN-1 overexpression suppressed micro-metastasis of MDA-MB-231 cells in nude mice. ${ }^{42}$ Conversely, an upregulation of $\operatorname{PrP}^{\mathrm{C}}$ expression was detected in metastatic gastric cancer, ${ }^{6}$ and its expression in pancreatic ductal adenocarcinoma was correlated with a marked decrease in patients' survival. ${ }^{43}$ Interestingly, we showed a significant re-distribution of PFN-1 in $\mathrm{PrP}^{\mathrm{C}}$-overexpressing versus control cells both exposed to STS. Furthermore, silencing of PFN-1 by siRNA resulted in a significant increase in viability and decrease in caspase-3 activity in $\mathrm{PrP}^{\mathrm{C}}$-overexpressing versus control cells under STS conditions. Even more important, a significant raise in viability and concomitant diminishment of caspase-3 activity was observed in $\mathrm{PrP}^{\mathrm{C}-}$ overexpressing cells in which PFN-1 was 

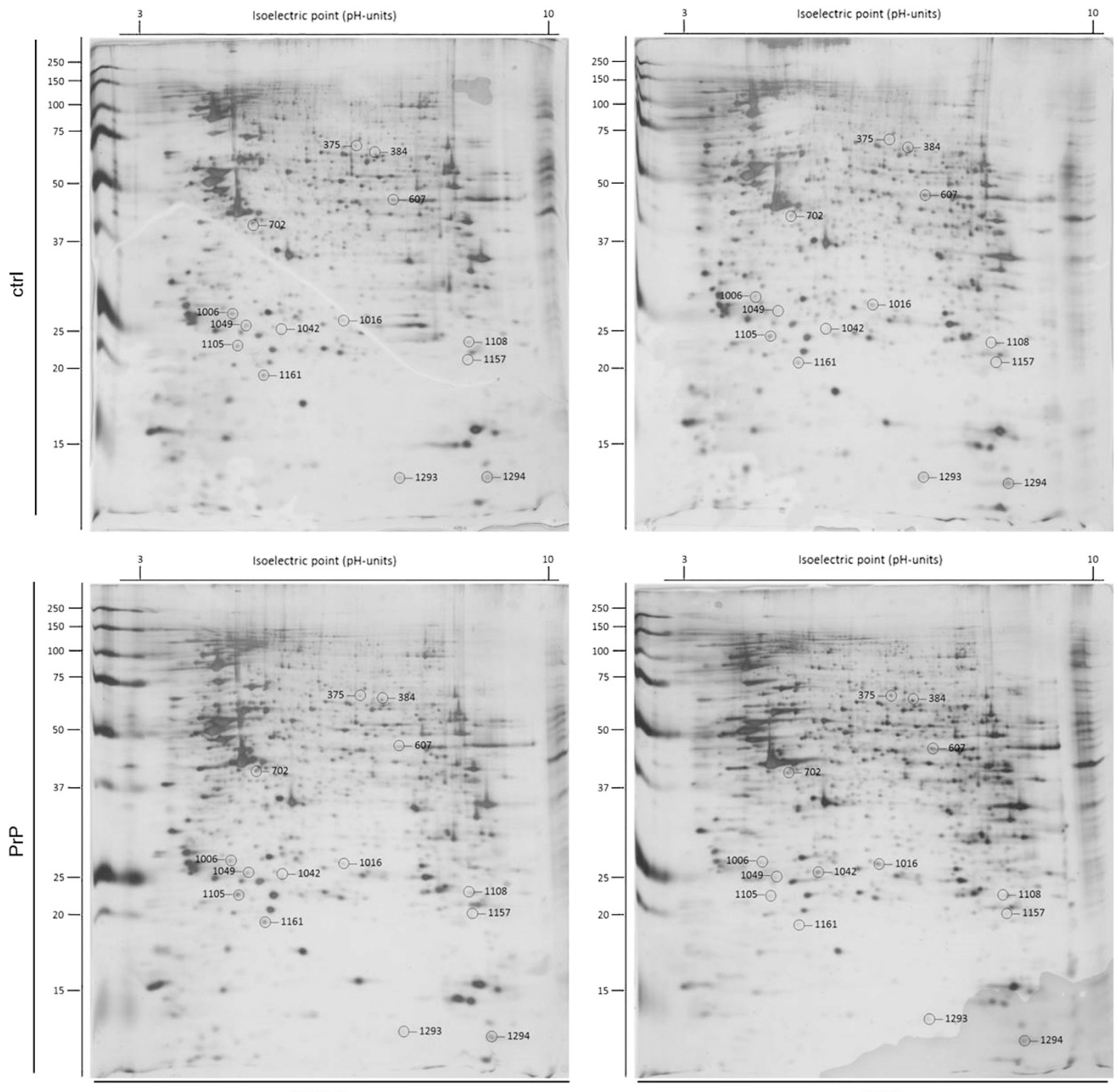

DMSO

STS

Figure 3 Silver-stained 2-DE gels of empty vector-and PrPc -overexpressing SH-SY5Y in the presence of DMSO/STS. Linear $17 \mathrm{~cm} \mathrm{IPG} \mathrm{strips} \mathrm{(pH} \mathrm{3-10)} \mathrm{were} \mathrm{used} \mathrm{and}$ loaded with $130 \mu \mathrm{g}$ of proteins. Labelling on the gel represents the location of 14 protein spots detected as differentially regulated between distinct transfection/treatment groups. Upper panels represent 2-DE gel pattern of SH-SY5Y cells stably transfected with an empty vector (designated ctrl), whereas lower panels represent the 2-DE pattern of SH-SY5Y cells stably overexpressing $\operatorname{PrP}^{\mathrm{C}}$ (designated PrP). The panels on the left side depict 2-DE pattern following DMSO treatment, whereas panels on the right side depict 2-DE pattern following STS treatment. The protein identity of spots is listed in Table 1

silenced versus $\mathrm{PrP}^{\mathrm{c}}$-overexpressing cells treated with mock control, both exposed to STS. These findings suggest that downregulation of PFN-1 may have a role in $\mathrm{PrP}^{\mathrm{c}}$-mediated protection against apoptotic cell death induced by STS. The established link between $\mathrm{PFN}-1$ and $\mathrm{PrP}^{\mathrm{C}}$ definitely deserves further attention.

Remarkably, p53 another tumor suppressor protein crucial for maintaining genetic stability and cellular redox status ${ }^{44,45}$ exhibited in the present study nearly identical expression pattern as the one observed for PFN-1. We detected significantly higher levels of p53 expression in control as compared with $\mathrm{PrP}^{\mathrm{c}}$-overexpressing cells under both experimental conditions. In resting cells p53 levels are low, whereas its levels increase because of rapid stabilization following exposure to different DNA-damaging agents and other stress stimuli. ${ }^{46}$ In earlier study, we observed no differences in p53 expression after stable $\mathrm{PrP}^{\mathrm{C}}$-overexpression in $\mathrm{SH}-\mathrm{SY} 5 \mathrm{Y}$ cells. ${ }^{17}$ However, it must be emphasized that in the latter study SH-SY5Y control cells were not stably transfected with an empty pClneo vector. Nevertheless, p53-dependent 

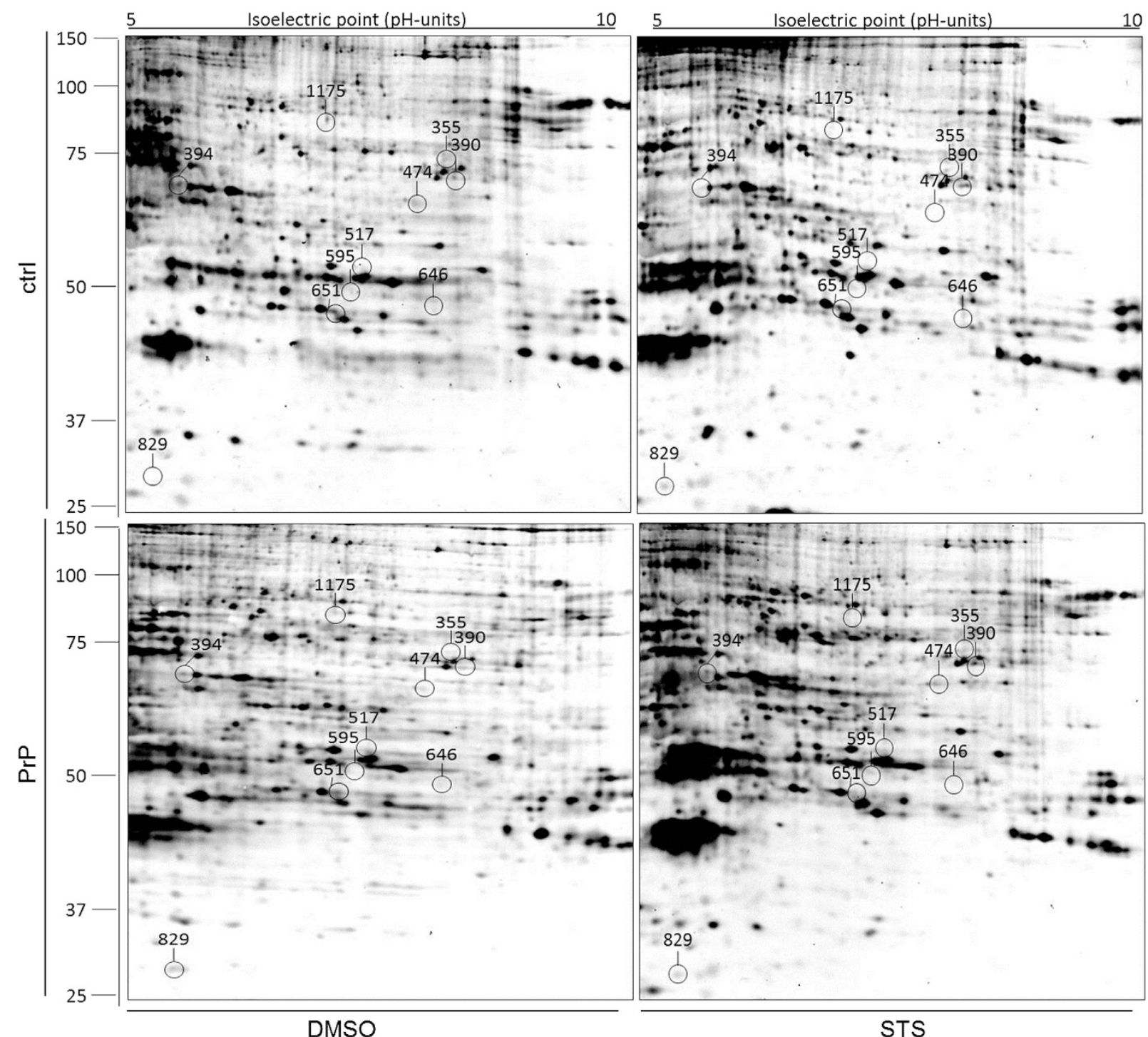

Figure 4 2-DE phospho-proteome of empty vector- and PrPc-overexpressing SH-SY5Y in the presence of DMSO/STS. Linear $17 \mathrm{~cm} \mathrm{IPG} \mathrm{strips} \mathrm{(pH} \mathrm{5-10)} \mathrm{were} \mathrm{used} \mathrm{and}$ loaded with $130 \mu \mathrm{g}$ of proteins. Labelling on the gel represents the location of 11 protein spots detected as differentially regulated between distinct transfection/treatment groups (spot no. 394 remained unidentified). Upper panels show representative gels of control cells, expressing endogenous levels of PrP ${ }^{c}$, whereas lower panels show representative gels of PrPC-overexpressing SH-SY5Y cells. The panels on the left side: DMSO (vehicle control); the panels on the right side: STS treatment. The protein identity of spots is listed in Table 2

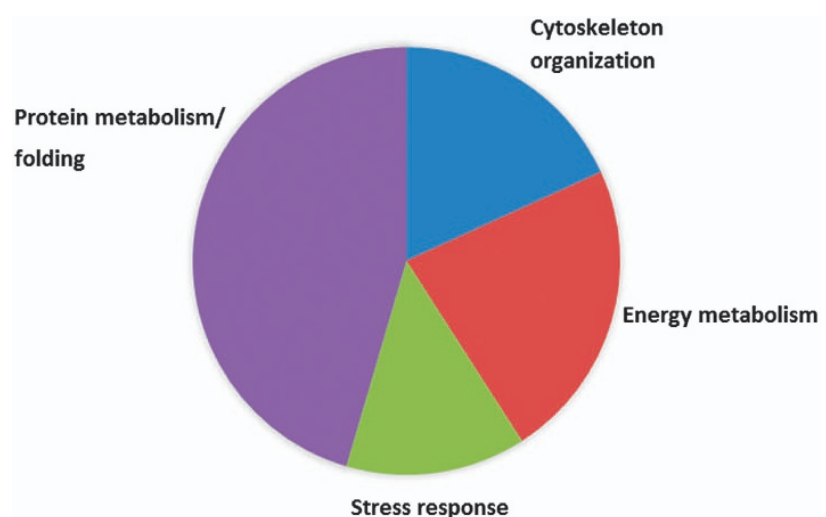

Figure 5 Distribution of all differentially regulated total and phospho-proteins in 2-DE in the form of functional categories activation of caspase-3 was repeatedly verified following STS treatment of both $\mathrm{PrP}^{\mathrm{C}}$-overexpressing and cells with endogenous $\mathrm{PrP}^{\mathrm{C}}$ levels. ${ }^{13,26}$ We suggest that higher expression of $\mathrm{PFN}-1$ and $\mathrm{p} 53$ in control as compared with $\mathrm{PrP}^{\mathrm{C}}$-overexpressing SH-SY5Y cells subjected to STS might contribute to apoptosis (caspase-3 activation) in the former versus the latter group.

Transgelin is another protein affecting dynamics of the actin cytoskeleton. $^{47}$ In the present study, western blot analysis exhibited approximately 45-fold higher expression of transgelin2 in $\mathrm{PrP}^{\mathrm{C}}$-overexpressing cells subjected to STS as compared with all other experimental conditions. Meanwhile, transgelin was identified as a repressor of metallo-matrix proteinase 9 (MMP-9) expression involved in ECM remodeling. ${ }^{48,49}$ Likewise, $\operatorname{PrP}^{\mathrm{C}}$ was shown to decrease MMP-9 transcript levels in neuronal cells. ${ }^{50}$ Moreover, a surplus of MMP-9 pro-apoptotic 
a

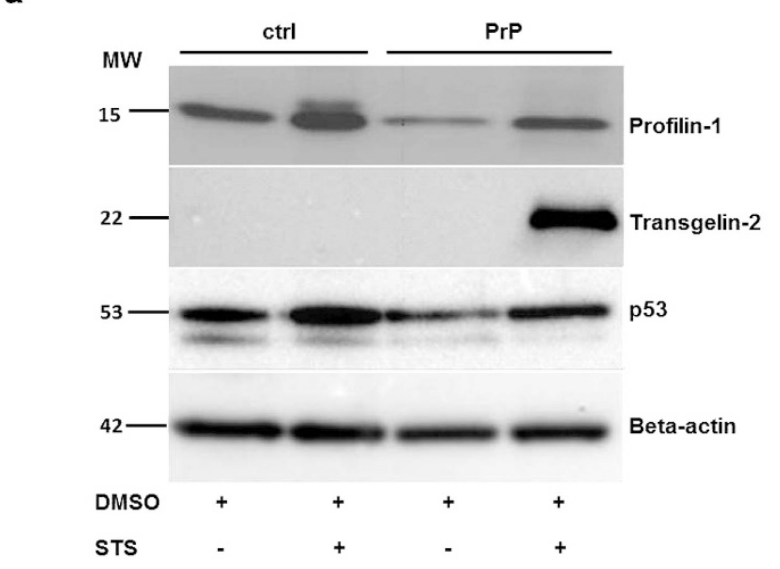

c

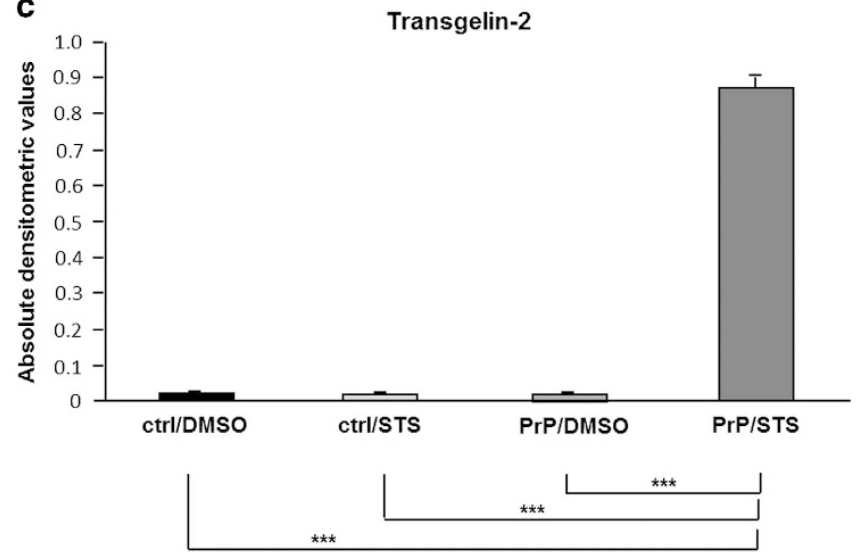

b

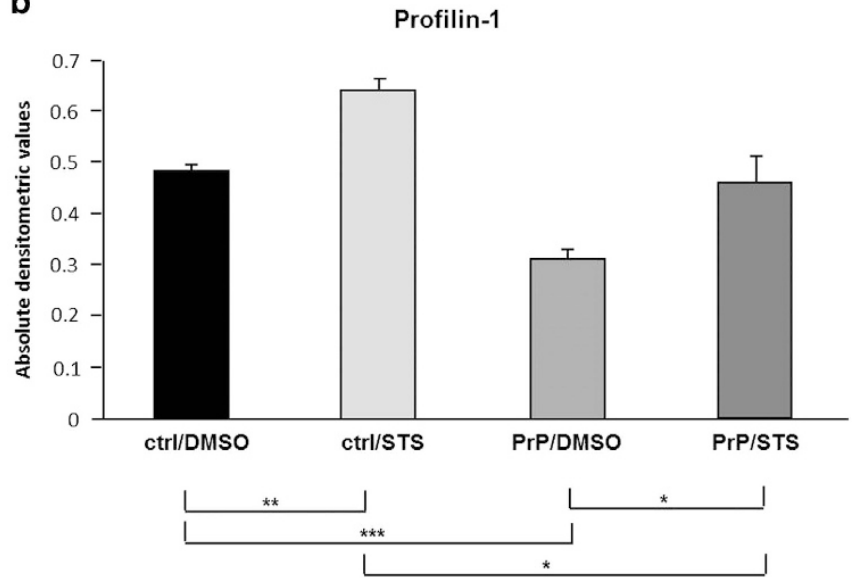

d

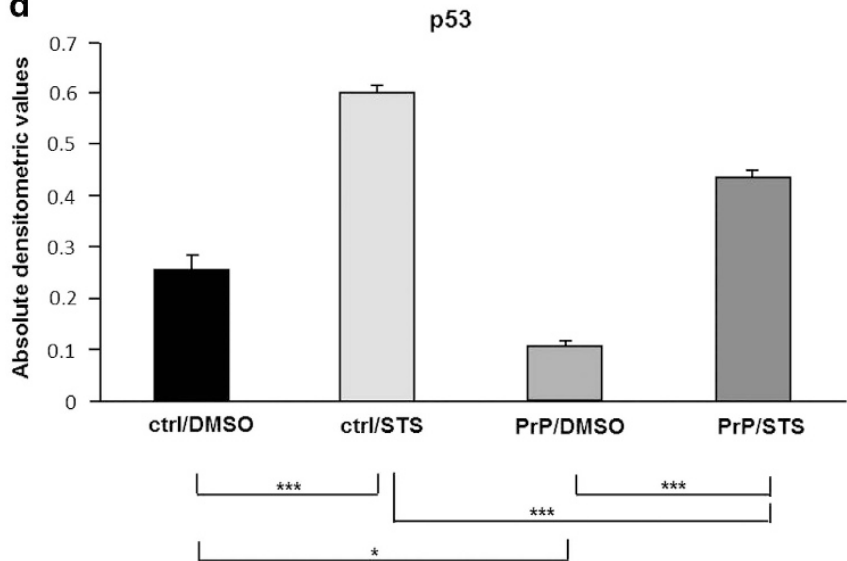

Figure 6 Profilin-1, transgelin-2 and p53 are differentially regulated between empty vector- and PrPc-overexpressing SH-SY5Y cells following DMSO/STS treatment. Western blot analysis shows a marked upregulation of profilin-1 in both empty vector (designated ctrl) and PrPc -overexpressing (designated PrP) SH-SY5Y cells subjected to STS as compared with DMSO treatment. An overexpression of $\mathrm{PrP}^{\mathrm{C}}$ significantly decreases profilin-1 expression, regardless of DMSO/STS treatment. Transgelin-2 expression was detected only in cells overexpressing PrPc subjected to STS treatment, whereas no signal was detected in PrPc-overexpressing cells subjected to DMSO. Likewise, no signal was obtained in control cells subjected either to DMSO or STS. p53 displays a similar expression pattern as profilin-1 with significantly higher expression in control as compared with $\mathrm{PrP}^{\mathrm{C}}$-overexpressing cells under both experimental conditions. $\beta$-actin expression below is given as a control for an equal protein load. The displayed Western blots are representatives of three independent experiments (a). Expression level of each protein displayed by western blot was quantified by densitometric analysis and is shown as a diagram $(\mathbf{b}-\mathbf{d})$. Data were normalized against $\beta$-actin and are given as a ratio of each protein $/ \beta$-actin \pm S.D., ${ }^{\star} P \leqslant 0.05 ;{ }^{* \star} P \leqslant 0.01 ;{ }^{* \star *} P \leqslant 0.001$

versus anti-apoptotic properties, ${ }^{51}$ especially during neuronal apoptosis, let us assume that $\mathrm{PrP}^{\mathrm{C}}$-mediated upregulation of transgelin-2 following STS treatment presumably led to downregulation of MMP-9 and, thus to a reduction of its pro-apoptotic properties.

Peroxiredoxin-4 (Prx-4), which belongs to a stress response functional group of proteins is an ER-localized enzyme ${ }^{52}$ that exhibits antioxidant properties and promotes cell survival. ${ }^{53,54}$ Peroxiredoxin-4 appears to provide a cytoprotective effect against environmental factors that raise levels of hydrogen peroxide in the lumen of ER. ${ }^{54}$ We observed 10-fold higher expression of Prx-4 in $\mathrm{PrP}^{\mathrm{C}}$-overexpressing versus control cells, both subjected to STS. We presume that $\mathrm{PrP}^{\mathrm{C}}$-overexpressing SH-SY5Y cells subjected to STS undergo less ER stress than the control cells because of their high Prx-4 expression. In line with this connotation, Cusinato et al. ${ }^{55}$ showed that when cellular ER stress is present STS effects are more potent.
The fact that protein phosphorylation is the most common post-translational modification in eukaryotic cells involved in all basic cellular processes prompted us to investigate phospho-proteome of $\mathrm{PrP}^{\mathrm{C}}$-overexpressing SH-SY5Y cells following STS treatment. Inositol monophosphatase 1 (IMPA1) phosphorylation status was decreased in $\mathrm{PrP}^{\mathrm{C}}$-overexpressing cells subjected to STS as compared with control cells subjected to the same conditions. Inhibition of IMPA1 is characterized by depletion of free inositol and a subsequent decrease of inositol-1,4,5-triphosphate $\left(\mathrm{IP}_{3}\right)$ levels resulting in induction of autophagy, ${ }^{56}$ which is generally known to block the induction of apoptosis. ${ }^{57}$ Another protein's phosphorylation level was exclusively increased by $\mathrm{PrP}^{\mathrm{C}}$-overexpression treated with STS: calcium-binding mitochondrial carrier protein SCaMC-1. This protein is beneficial for counteracting $\mathrm{Ca}^{2+}$ overload-induced cell death, ${ }^{58}$ and STS is known to provoke cytosolic and mitochondrial $\mathrm{Ca}^{2+}$ overload, a critical event for initiation of cell death. ${ }^{59}$ 

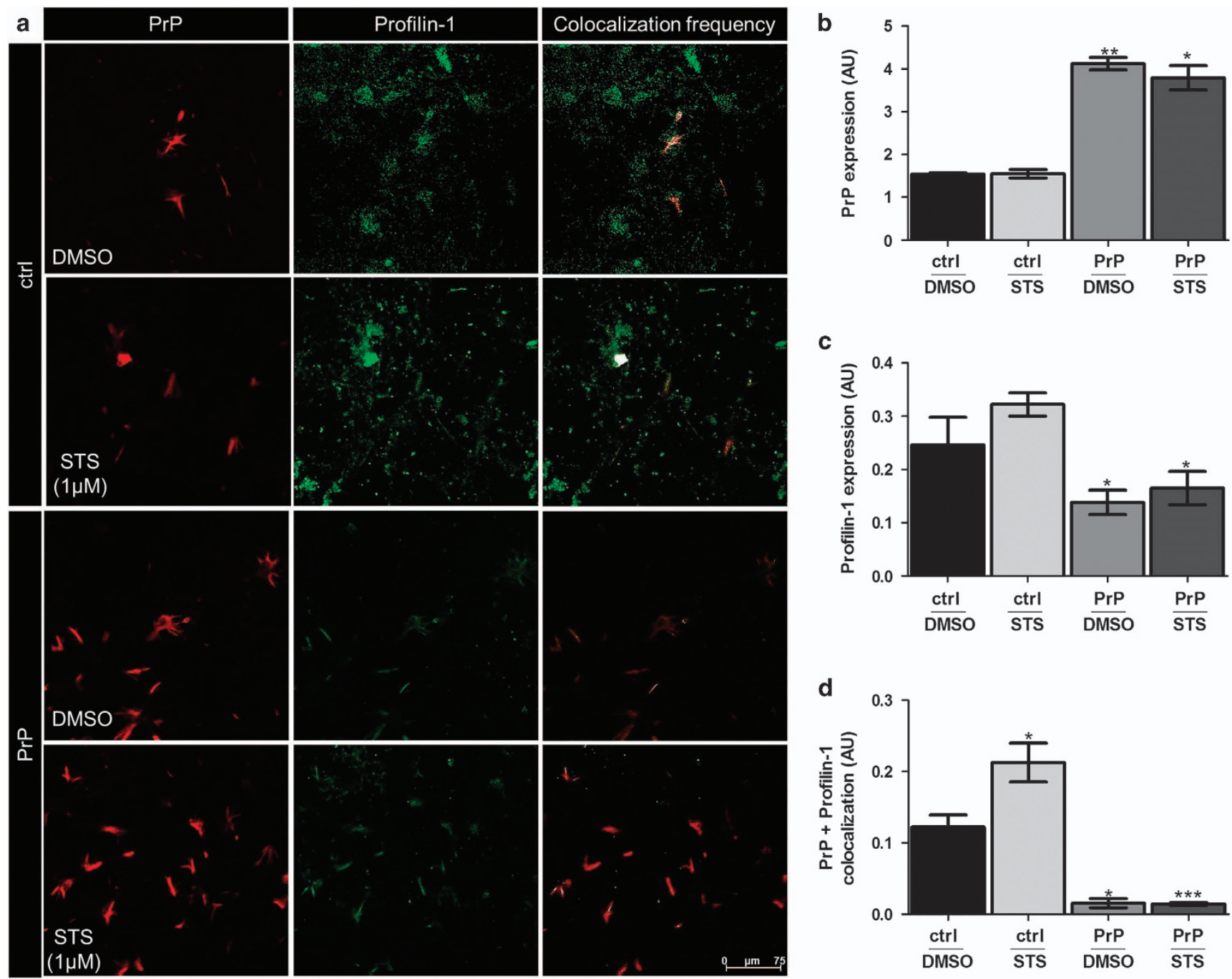

C
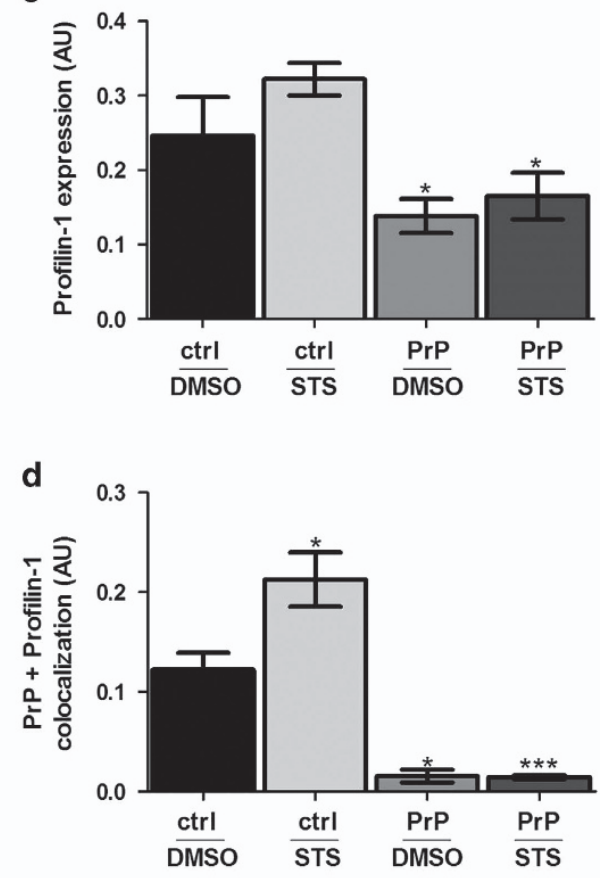

Figure 7 Co-localization of profilin-1 and $\mathrm{PrP}^{\mathrm{C}}$ in SH-SY5Y cells following DMSO/STS treatment. Co-immunostaining of profilin-1 and PrPc shows a marked altered localization of profilin-1 in both empty vector (designated ctrl) and PrPc-overexpressing (designated PrP) SH-SY5Y cells subjected to STS as compared with DMSO treatment (a). Quantification of images taken in different regions of SH-SY5Y cells fixed after STS treatment showed a significant re-distribution of profilin-1 in PrP-positive cells. Pearson's co-localization correlation coefficient $r p(-1 \leqslant r p \leqslant 1)$ and graph was generated by ImageJ (Bethesda, MD, USA) (WCIF plugin) software. Densitometric analysis was performed from four independent experiments and the level of significance was calculated using one-way ANOVA Friedman test: ${ }^{*} P \leqslant 0.05 ;{ }^{* *} P \leqslant 0.01 ;{ }^{* * *} P \leqslant 0.001$ (b-d)

Provansal et al. ${ }^{34}$ identified two proteins modulated after prion infection, which revealed changed phosphorylation status in the present study: stomatin-like protein 2, involved in mitochondrial biogenesis ${ }^{60}$ and T-complex protein 1, a molecular chaperone. Not only that stomatin-like protein 2 phosphorylation status was decreased in $\mathrm{PrP}^{\mathrm{C}}$-overexpressing cells, but also its expression level was down-regulated following $\mathrm{PrP}^{\mathrm{C}}$-overexpression in $\mathrm{SH}-\mathrm{SY} 5 \mathrm{Y}$ cells treated with STS. On the contrary, T-complex protein 1 showed an increased phosphorylation on $\mathrm{PrP}^{\mathrm{C}}$ overexpression.

Cystathionine-beta synthase (CBS), an enzyme primarily localized in the brain, important for cellular $\mathrm{H}_{2} \mathrm{~S}$ production ${ }^{61}$ exhibited diminished phosphorylation in $\mathrm{PrP}^{\mathrm{C}}$-overexpressing cells subjected to both DMSO and STS. $\mathrm{H}_{2} \mathrm{~S}$ appears to have oxygen sensor properties and to be involved in regulation of energy metabolism. ${ }^{62}$ CBS phosphorylation at Ser 227 has been shown to modulate its catalytic activity and thereby $\mathrm{H}_{2} \mathrm{~S}$ production. ${ }^{63}$ The possible role of $\mathrm{PrP}^{\mathrm{c}}$ in regulating phosphorylation status of CBS remains to be elucidated.

Altogether, $\mathrm{PrP}^{\mathrm{C}}$-overexpression in $\mathrm{SH}-\mathrm{SY} 5 \mathrm{Y}$ cells per se appears to stress the cells as observed by decreased cell viability under control conditions. However, after exposure to STS, higher levels of $\mathrm{PrP}^{\mathrm{C}}$ become beneficial in terms of cell survival and apoptosis as compared with endogenous $\operatorname{PrP}^{\mathrm{C}}$ levels. Proteome and phospho-proteome indicate major changes in protein metabolism/folding, energy metabolism, cytoskeleton and stress response group between the both experimental groups. Although not identified during proteome analysis, we confirm differential regulation of tumor suppressor p53 by different $\mathrm{PrP}^{\mathrm{C}}$ levels under non-apoptotic and apoptotic conditions.

In our opinion the established link between $\mathrm{PrP}^{\mathrm{C}}$ and PFN-1 deserves a special attention given PFN-1 role in tumor suppression on one side and $\mathrm{PrP}^{\mathrm{c}}$ role as a promotor of 
a

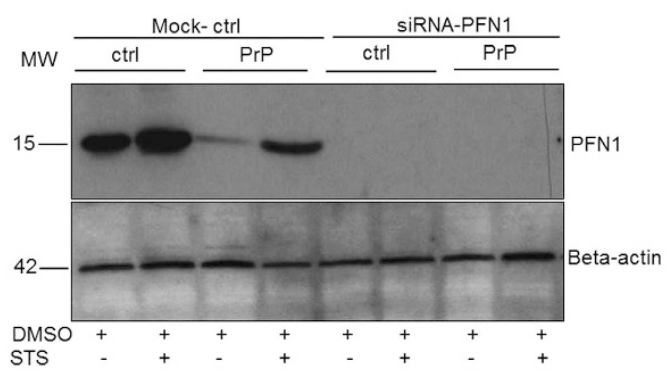

b

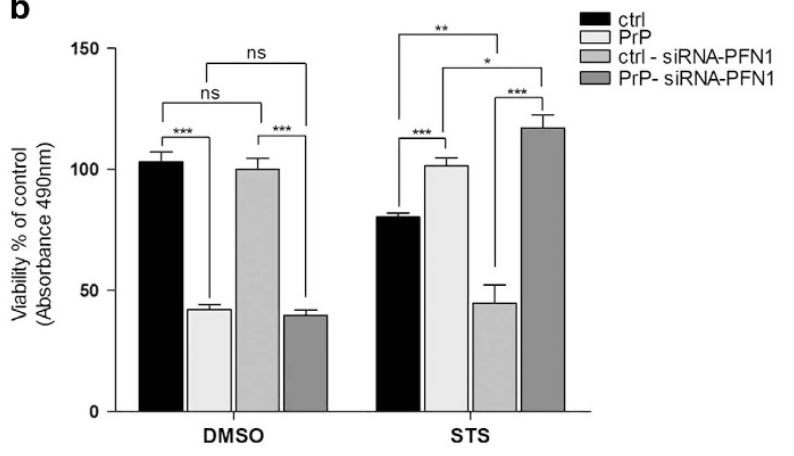

c

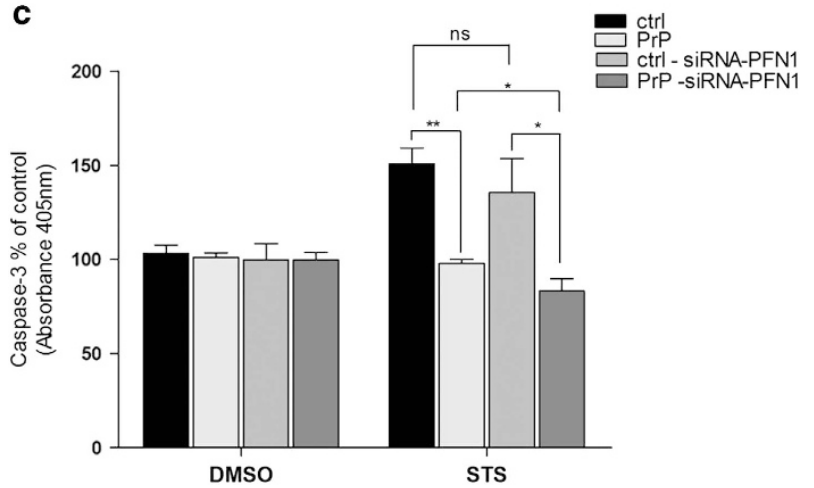

Figure 8 Silencing of profilin-1 expression in SH-SY5Y cells using siRNA. Western blot displays profilin-1 expression after transfection with non-targeting mock control (designated Mock-ctrl) and following transfection with profilin-1 specific siRNA (siRNA-PFN-1). Cells expressing endogenous levels of $\mathrm{PrP}^{\mathrm{C}}$ (designated ctrl) and $\mathrm{PrP}^{\mathrm{c}}$-overexpressing cells (designated PrP) were both subjected to $2 \mathrm{~h}$ treatment with $1 \mu \mathrm{M}$ STS or DMSO. Markedly higher profilin-1 expression is present in control versus PrP cells both treated with mock control. No profilin-1 expression after transfection with siRNA-PFN-1 was visible after immunoblotting. Beta-actin expression is given as a control for an equal protein load (a). Cell viability was measured by MTS assay $24 \mathrm{~h}$ post-transfection and $2 \mathrm{~h}$ after $1 \mu \mathrm{M}$ STS or DMSO treatment. Note, increase in cell viability of PrP cells after silencing profilin-1 expression under STS treatment versus control cells subjected to the same conditions. PrP cells treated with siRNA-PFN-1 exhibit a significant increase in viability as compared with PrP cells treated with mock control. (b) Caspase-3 activity was reduced in PrP cells depleted of profilin-1 and treated with STS as compared with control cells under same experimental conditions. In addition, slight but significant decrease in caspase-3 activity was observed in PrP-siRNA-PFN-1 treated cells as compared with $\mathrm{PrP}^{\mathrm{C}}$-overexpressing cells not depleted of profilin-1 (PrP), both exposed to STS (c). Values represent the mean \pm S.D. of four independent experiments. Level of significance was calculated using Student's $t$-test: ${ }^{*} P \leqslant 0.05$; ${ }^{* *} P \leqslant 0.01 ;{ }^{* * *} P \leqslant 0.001$

cancer cell invasiveness on the other. Reduction of PFN-1 expression by elevated $\operatorname{PrP}^{\mathrm{c}}$ levels might prove important not only as so far unrecognized contributing factor for increased resistance of $\mathrm{PrP}^{\mathrm{C}}$-overexpressing SH-SY5Y cells to STS- induced apoptosis, but also in the light of emerging roles of these two proteins in cancer.

\section{Materials and Methods}

Cell culture, stable transfection and staurosporine treatment. SH-SY5Y human neuroblastoma cells constitutively and stably expressing full-length human $\mathrm{PrP}^{\mathrm{C}}$ were established and maintained as previously described. ${ }^{17}$ In addition, control transfected SH-SY5Y cells stably expressing pClneo plasmid (Promega, Mannheim, Germany) without a human prion protein gene (PRNP) insert were generated in the same manner. Both cell lines were grown in Dulbecco's modified Eagle medium (DMEM; Biochrom, Berlin, Germany) supplemented with $10 \%$ heat-inactivated fetal calf serum (FCS; Biochrom), 1\% penicillin/streptomycin (P/S; Biochrom) and $1 \%$ L-glutamine (Biochrom) at $37{ }^{\circ} \mathrm{C}, 5 \% \mathrm{CO}_{2}$ supply and $95 \%$ humidity. Six weeks after addition of $400 \mu \mathrm{g} / \mathrm{ml}$ Geneticin (Gibco/Invitrogen, Karlsruhe, Germany) both stably transfected cell lines were selected and further maintained in the same medium with a lower Geneticin concentration $(200 \mu \mathrm{g} / \mathrm{ml})$. Before induction of apoptotic cell death by STS in empty vector- and PRNP-transfected SH-SY5Y cells, cell medium containing Geneticin was aspirated and a fresh medium without Geneticin was added. Apoptosis was induced by exposure of cells to $1 \mu \mathrm{M}$ STS (Sigma-Aldrich, Taufkirchen, Germany) for $2 \mathrm{~h}$. Staurosporine was dissolved in dimethyl sulfoxide (DMSO; Sigma-Aldrich). Control cells received vehicle, $0.1 \%$ DMSO. After $2 \mathrm{~h}$ of exposure to either STS or DMSO cells were washed twice with phosphate-buffered saline (PBS) and collected for further analyses.

siRNA and transfection. For silencing of profilin-1 gene expression 200000 cells per well in a 6-well plate were seeded in complete DMEM medium (Biochrom) before transient transfection with siRNA duplexes, using Lipofectamine 2000 (Invitrogen, Carlsbad, CA, USA) according to the manufacturer's instructions. After $24 \mathrm{~h}$ in complete DMEM, cells were re-suspended in Opti-MEM I reduced serum medium (ThermoFischer Scientific, Darmstadt, Germany) and transfected either with $200 \mathrm{pmol} / /$ profilin-1-specific siRNAs (catalog number sc-36316-Santa Cruz Biotechnology, Dallas, TX, USA) containing three different sequences: GUGUCCUGGUUGGCAAAGA, CACGGUGGUUUGAUCAACA, and CCCCAUACC CCUUAUUGCU ${ }^{64}$ or with equimolar non-targeting siRNA duplex (control siRNA duplex negative control: Eurogentec, Cologne, Germany) as a negative control. Six hours post-transfection Opti-MEM was replaced with complete DMEM and cells were incubated for another $18 \mathrm{~h}$. Subsequently, $1 \mu \mathrm{M} \mathrm{STS}$ or DMSO were added for another $2 \mathrm{~h}$ before processing cells for MTS proliferation and caspase- 3 activity assay (please see below)

Silver staining and densitometric analysis. The $17 \mathrm{~cm}$ gels were silver stained as previously described. ${ }^{65}$ Briefly, gels were fixed in $50 \%$ methanol, $12 \%$ acetic acid for $1 \mathrm{~h}$ at room temperature (RT) on an orbital shaker, washed for $40 \mathrm{~min}$ in $50 \%$ ethanol and sensitized with $0.8 \mathrm{mM}$ sodium thiosulfate for $60 \mathrm{~s}$. The gels were then incubated in freshly prepared silver nitrate solution $(0.2 \%$ silver nitrate and $0.026 \%$ formaldehyde) for $20 \mathrm{~min}$ at RT followed by three washing steps of $20 \mathrm{~s}$ each, in distilled water. Finally, gels were placed in a developing solution $(6 \%$ sodium carbonate, $0.0185 \%$ formaldehyde and $0.05 \%$ sodium thiosulfate) until standard markers were stained completely and adequate spots visualized. Gels were scanned with a Gel CanoScan $8400 \mathrm{~F}$ (Canon, Tokyo, Japan). Densitometric analyses were performed using Delta 2D software version 3.6 (Decodon $\mathrm{GmbH}$, Greifswald, Germany). Furthermore, the intensities of the spots were normalized by dividing the intensity of each spot by the sum of all spot intensities on the corresponding gels. Fold change, standard deviation and Student's $t$-test significance level were calculated using Microsoft excel software. Spots having at least 1.5 -fold expressional changes $(P \leqslant 0.05)$ were considered statistically significant. The spots of interest were excised from the silver stained gels, in-gel protein digested and extracted peptides were subjected to the mass spectrometric based MS/MS protein identification analysis (please see Supplementary Table 1) as described earlier. ${ }^{66}$ Acceptance criteria was set to at least two sequenced peptides per protein spot. Four independent 2-DE experiments were performed.

Phospho-specific staining of 2-DE gels. Gels were fixed twice in a solution containing $50 \%$ methanol and $10 \%$ acetic acid for $45 \mathrm{~min}$ and washed three times in double distilled water for $15 \mathrm{~min}$ each. Gels were incubated in Pro-Q Diamond phospho-stain (Invitrogen, Paisley, UK) overnight in the dark at RT, distained in $20 \%$ acetonitrile and $50 \mathrm{mM}$ sodium acetate three times for $30 \mathrm{~min}$, 
followed by three washing steps in double distilled water for 5 min each. Gels were scanned using an imaging instrument (FLA -5100 Fuji photo film, Dusseldorf, Germany) at a wavelength of $532 \mathrm{~nm}$. Fold change, standard deviation and Student's t-test level of significance were calculated using Microsoft excel software. Spots having at least 1.4 -fold expressional changes $(P \leqslant 0.05)$ were considered statistically significant. In-gel protein digestion and MS/MS analysis (please see Supplementary Table 2) were performed as described in the section 'Silver staining and densitometric analysis'. Acceptance criteria was set to at least two sequenced peptides per protein spot. Four independent 2-DE experiments were performed.

Antibodies and immunoblot analysis. Primary antibodies used for immunoblot analysis were monoclonal mouse anti-transgelin-2 (1:1000) (Abcam, Cambridge, UK), monoclonal mouse anti-p53 (1:1000) (Abcam), monoclonal mouse anti-beta-actin (1:5000 Abcam) and monoclonal rabbit anti-profilin-1 (1:1000) (Abcam). Secondary antibodies used were horseradish peroxidase (HRP)conjugated rabbit anti-mouse (IBA, Goettingen, Germany) and goat anti-rabbit (Jackson Immunoresearch Laboratories, Palo Alto, CA, USA).

Cell lysis extraction and immunoblotting were performed as described previously. ${ }^{67}$ Briefly, cells were lysed $(50 \mathrm{mM}$ Tris- $\mathrm{HCl}, \mathrm{pH}=8,1 \%$ Triton X-100, 0.5\% CHAPS, $1 \mathrm{mM}$ DTT), and lysates were cleared of cell debris $\left(1 \mathrm{~min}\right.$ at $\left.1000 \times \mathrm{g}, 4^{\circ} \mathrm{C}\right)$. Cell lysates were supplemented with protease and phosphatase inhibitor cocktail (Roche, Mannheim, Germany) and were separated on $12.5 \%$ SDS-PAGE. Immunoblotting was performed using above mentioned primary antibodies overnight at $4{ }^{\circ} \mathrm{C}$. Membranes were then rinsed three times in $1 \times$ Tris-buffered saline with Tween-20 (TBS-T) and incubated with the corresponding HRP-conjugated secondary antibody (diluted 1:2000; 1:5000) for $1 \mathrm{~h}$ at RT. Immunoreactivity was detected after immersion of the membranes into enhanced chemiluminescence $(E C L)$ solution and exposure to ECL-Hyperfilm (Amersham Biosciences, Buckinghamshire, UK). Images were documented using the ScanMaker4 (Microtek, Kiel, Germany, International), after correction for the background, and band intensities were determined by densitometry using Labimage (version 2.7.1, Kapelan GmbH, Germany) data analyzer software. For each condition analysed, three western blots were prepared from three or four different protein extractions.

Determination of cell viability. Cell viability was determined by the MTS proliferation assay (Promega, Madison, WI, USA), which measures reduction of [3-(4,5-dimethylthiazol-2-yl)-5-(3-carboxymethoxyphenyl)-2-(-4-sulfophenyl)-2H-tetrazolium] (MTS) to a water soluble formazan salt, which occurs only in metabolically active cells. Both control- and PRNP-stably transfected SH-SY5Y neuroblastoma cells were grown in $75 \mathrm{~cm}^{2}$ culture flasks at $37^{\circ} \mathrm{C}$ in a $5 \% \mathrm{CO}_{2}$ atmosphere until reaching $60-70 \%$ confluency. Subsequently, cells were either treated with $1 \mu \mathrm{M}$ STS or DMSO (vehicle control) for $2 \mathrm{~h}$ or were left untreated (negative control), rinsed with cold $1 \times \mathrm{PBS}$ and detached from the flask surface using trypsin-EDTA solution. After centrifugation at $400 \times g$ for $5 \mathrm{~min}$ at $4{ }^{\circ} \mathrm{C}$ cells were re-suspended in a cell culture medium, seeded into 24 -well plates (Nunc, Roskilde, Denmark) at cell density of $1 \times 10^{5}$ cells per well and incubated for $12 \mathrm{~h}$ at $37^{\circ} \mathrm{C}$. The cell viability was quantitatively assessed by using MTS reagent in the presence of phenazine methyl sulphate (PMS). After addition of combined MTS/PMS solution into each well, plates were incubated in a humidified atmosphere containing $5 \% \mathrm{CO}_{2}$ for $1 \mathrm{~h}$ at $37^{\circ} \mathrm{C}$. The absorbance values were read at $490 \mathrm{~nm}$ using a Multiscan plate reader (Labsystems, Manassas, VA, USA) and Accent software 2.6. Cell-free background absorbance of the medium incubated with the MTS reagent was subtracted from sample wells to obtain the final absorbance values. All MTS assays were performed in triplicates.

Caspase-3 activity measurements. The caspase- 3 activity assay (Promega) enables quantitative assessment of caspase-3 (DEVDase) protease activity, an early apoptotic event. The assay was performed according to the manufacturer's recommendations. Briefly, the cell density of empty vector- and PRNPstably transfected SH-SY5Y cells was adjusted to $5 \times 10^{5}$ cells per ml. Twenty-four hours later cells were either left untreated (negative control), were treated with DMSO (vehicle control) or with $1 \mu \mathrm{M}$ STS for $2 \mathrm{~h}$ at $37^{\circ} \mathrm{C}$ in a humidified, $5 \% \mathrm{CO}_{2}$ atmosphere. As an additional control for inhibition of apoptosis, the caspase inhibitor Z-VAD-FMK was concomitantly added in a final concentration of $50 \mu \mathrm{M}$ to a fraction of cells treated with $1 \mu \mathrm{M}$ STS. Afterwards, cells were rinsed with ice-cold PBS, gently scraped, collected by centrifugation and finally lysed in the cell lysis buffer for $15 \mathrm{~min}$ at $4^{\circ} \mathrm{C}$. Cell lysates were centrifuged at $15000 \times \mathrm{g}$ for $20 \mathrm{~min}$ at $4^{\circ} \mathrm{C}$. Protein concentration was estimated by the Bradford assay (Bio-Rad, Munich, Germany) and the total cell lysate $(50 \mu \mathrm{g})$ was then incubated with $200 \mu \mathrm{M}$ caspase-3 specific substrate DEVD-pNA for $4-5 \mathrm{~h}$ at $37^{\circ} \mathrm{C}$. Caspase-3-mediated release of $p$-nitroaniline (pNA) was measured by absorbance at $405 \mathrm{~nm}$. Background absorbance from the control (untreated cells) was subtracted from the samples after the final absorbance was obtained. All caspase assays were performed in quadruplicates.

PrP $^{c}$ ELISA. PrP ${ }^{c}$ ELISA was performed by using BSE-Detection Kit (Bio-Rad Laboratories $\mathrm{GmbH}$ ) according to the instructions of the supplier. Briefly, equal amounts of protein from empty vector- and PRNP-stably transfected SH-SY5Y cells were added to a microtiter plate coated with a monoclonal anti-PrP antibody and incubated for $75 \mathrm{~min}$ at $37^{\circ} \mathrm{C}$. Recombinant human prion protein (Prionics, Zurich, Switzerland) was used as a positive control. After several washing steps a monoclonal anti-PrP antibody was added followed by incubation for 60 min at $4{ }^{\circ} \mathrm{C}$. After incubation with a developing solution containing $\mathrm{H}_{2} \mathrm{O}_{2}$ and tetramethylbenzidine (30 min at RT) reaction was stopped, extinction was measured (at 450/620 nm) and $\mathrm{PrP}^{\mathrm{C}}$ content was determined (ng/ $\mu \mathrm{l}$ protein).

Statistical analysis. Densitometric values of 2-DE gels and western blot bands as well as the values obtained from cell viability and caspase-3 activity assays were statistically assessed using unpaired two-sided Student's $t$-test. Means and S.D. were calculated from three to four independent set of experiments. Differences with $P \leqslant 0.05$ value were considered statistically significant.

\section{Conflict of Interest}

The authors declare no conflict of interest.

Acknowledgements. This work was partially supported by a European Commission Grant (Prionscreen, FP6-SP5A-CT-2007-044438). We acknowledge the support by the German Research Foundation (DFG) and the Open Access Publication Fund of the University Medical Center Göttingen. We are indebted to Mrs. Manuela Becker, Mrs. Christina Wiese and Mrs. Susanne Goldmann for their excellent technical support at various stages of this investigationn

1. Meier P, Finch A, Evan G. Apoptosis in development. Nature 2000; 407: 796-801.

2. Yuan J, Yankner BA. Apoptosis in the nervous system. Nature 2000; 407: 802-809.

3. Wong RSY. Apoptosis in cancer: from pathogenesis to treatment. $J$ Exp Clin Cancer Res 2011; 30: 87.

4. Kretzschmar HA, Giese A, Brown DR, Herms J, Keller B, Schmidt B et al. Cell death in prion disease. J Neural Transm Suppl 1997; 50: 191-210.

5. Kellett KA, Hooper NM. Prion protein and Alzheimer disease. Prion 2009; 3: 190-194.

6. Pan Y, Zhao L, Liang J, Liu J, Shi Y, Liu N et al. Cellular prion protein promotes invasion and metastasis of gastric cancer. FASEB J 2006; 20: 1886-1888.

7. Chieng CK, Say YH. Cellular prion protein contributes to LS $174 \mathrm{~T}$ colon cancer cell carcinogenesis by increasing invasiveness and resistance against doxorubicin-induced apoptosis. Tumour Biol 2015; 36: 8107-8120.

8. Dickson DW. Apoptotic mechanisms in Alzheimer neurofibrillary degeneration: cause or effect? J Clin Invest 2004; 114: 23-27.

9. Kuwahara C, Takeuchi AM, Nishimura T, Haraguchi K, Kubosaki A, Matsumoto $Y$ et al Prions prevent neuronal cell-line death. Nature 1999; 400: 225-226.

10. Walz R, Amaral OB, Rockenbach IC, Roesler R, Izquierdo I, Cavalheiro EA et al. Increased sensitivity to seizures in mice lacking cellular prion protein. Epilepsia 1999; 40: 1679-1682.

11. Weise J, Crome O, Sandau R, Schulz-Schaeffer W, Bahr M, Zerr I. Upregulation of cellular prion protein $(\mathrm{PrPc})$ after focal cerebral ischemia and influence of lesion severity. Neurosci Lett 2004; 372: 146-150.

12. Paitel E, Alves da Costa C, Vilette D, Grassi J, Checler F. Overexpression of PrPc triggers caspase 3 activation: potentiation by proteasome inhibitors and blockade by anti-PrP antibodies. J Neurochem 2002; 83: 1208-1214.

13. Paitel $E$, Fahraeus $R$, Checler $F$. Cellular prion protein sensitizes neurons to apoptotic stimuli through Mdm2-regulated and p53-dependent caspase 3-like activation. J Biol Chem 2003; 278: $10061-10066$.

14. Westaway D, DeArmond SJ, Cayetano-Canlas J, Groth D, Foster D, Yang SL et al. Degeneration of skeletal muscle, peripheral nerves, and the central nervous system in transgenic mice overexpressing wild-type prion proteins. Cell 1994; 76: 117-129.

15. Chiesa R, Piccardo P, Biasini E, Ghetti B, Harris DA. Aggregated, wild type prion protein causes neurological dysfunction and synaptic abnormalities. J Neurosci 2008; 28: 13258-13267.

16. Huang S, Liang J, Zheng M, Li X, Wang M, Wang $P$ et al. Inducible overexpression of wildtype prion protein in the muscles leads to a primary myopathy in transgenic mice. Proc Nat Acad Sci USA 2007; 104: 6800-6805.

17. Weiss E, Ramljak S, Asif AR, Ciesielczyk B, Schmitz M, Gawinecka J et al. Cellular prion protein $\left(\mathrm{PrP}^{\mathrm{C}}\right)$ overexpression disturbs cellular homeostasis in SH-SY5Y neuroblastoma 
cells but does not alter p53 expression: a proteomic study. Neuroscience 2010; 169 . $1640-1650$.

18. Zhang Y, Qin K, Wang J, Hung T, Zhao RY. Dividing roles of prion protein in staurosporinemediated apoptosis. Biochem Biophys Res Commun 2006; 349: 759-768.

19. Liberski PP, Sikorska B, Bratosiewicz-Wasik J, Gajdusek DC, Brown P. Neuronal cell death in transmissible spongiform encephalopathies (prion diseases) revisited: from apoptosis to autophagy. Int J Biochem Cell Biol 2004; 36: 2473-2490.

20. Kriem B, Sponne I, Fifre A, Malaplate-Armand C, Lozac'h-Pillot K, Koziel V et al. Cytosolic phospholipase $A 2$ mediates neuronal apoptosis induced by soluble oligomers of the amyloid- $\beta$ peptide. FASEB J 2005; 19: 85-87.

21. Falcieri E, Martelli AM, Bareggi R, Cataldi A, Cocco L. The protein kinase inhibitor staurosporine induces morphological changes typical of apoptosis in MOLT-4 cells without concomitant DNA fragmentation. Biochem Biophys Res Commun 1993; 193: 19-25.

22. Suzuki K, Azuma Y, Onishi Y, Kizaki H, Ishimura Y. Biphasic effect of staurosporine on thymocyte apoptosis. Biochem Mol Biol Int 1995; 35: 1085-1092.

23. Philpott KL, McCarthy MJ, Becker D, Gatchalian C, Rubin LL. Morphological and biochemical changes in neurons: apoptosis versus mitosis. Eur J Neurosci 1996; 8: 1906-1915.

24. Cullen SP, Martin SJ. Caspase activation pathways: some recent progress. Cell Death Differ 2009; 16: 935-938.

25. Schmitz M, Zafar S, Silva CJ, Zerr I. Behavioral abnormalities in prion protein knockout mice and the potential relevance of $\operatorname{PrP}^{\mathrm{C}}$ for the cytoskeleton. Prion 2014; 8: 381-386.

26. Paitel E, Sunyach C, Alves da Costa C, Bourdon J-C, Vincent B, Checler F. Primary cultured neurons devoid of cellular prion display lower responsiveness to staurosporine through the control of p53 at both transcriptional and post-translational levels. J Biol Chem 2004; 279: 612-618.

27. Yao W, Cai X, Liu C, Qin Y, Cheng H, Ji S et al. Profilin 1 potentiates apoptosis induced by staurosporine in cancer cells. Curr Mol Med 2013; 13: 417-428.

28. Roucou X, LeBlanc AC. Cellular prion protein neuroprotective function: implications in prion diseases. J Mol Med 2005; 83: 3-11.

29. Diarra-Mehrpour M, Arrabal S, Jalil A, Pinson X, Gaudin C, Pietu G et al. Prion protein prevents human breast carcinoma cell line from tumor necrosis factor alpha-induced cell death. Cancer Res 2004; 64: 719-727.

30. Deshmukh M, Johnson EM Jr. Staurosporine-induced neuronal death: multiple mechanisms and methodological implications. Cell Death Differ 2000; 7: 250-261.

31. Zhang D, Richardson DR. Endoplasmic reticulum protein 29 (ERp29): an emerging role in cancer. Int J Biochem Cell Biol 2011; 43: 33-36.

32. Liu R, Zhao W, Zhao Q, Liu SJ, Liu J, He M et al. Endoplasmic reticulum protein 29 protects cortical neurons from apoptosis and promoting corticospinal tract regeneration to improve neural behaviour via caspase and Erk signal in rats with spinal cord transection. Mol Neurobiol 2014; 50: 1035-1048.

33. Short DM, Heron ID, Birse-Archbold JL, Kerr LE, Sharkey J, McCulloch J. Apoptosis induced by staurosporine alters chaperone and endoplasmic reticulum proteins: Identification by quantitative proteomics. Proteomics 2007; 7: 3085-3096.

34. Provansal M, Roche S, Pastore M, Casanova D, Belondrade M, Alais S et al. Proteomic consequences of expression and pathological conversion of the prion protein in inducible neuroblastoma N2a cells. Prion 2010; 4: 292-301.

35. Kim H, Sengupta A, Glogauer M, McCulloch CA. Filamin A regulates cell spreading and survival via beta1 integrins. Exp Cell Res 2008; 314: 834-846.

36. Coleman ML, Olson MF. Rho GTPase signalling pathways in the morphological changes associated with apoptosis. Cell Death Differ 2002; 9: 493-504.

37. Gill AC, Ritchie MA, Hunt LG, Steane SE, Davies KG, Bocking SP et al. Post-translational hydoxylation at the $\mathrm{N}$-terminus of the prion protein reveals presence of PPII structure in vivo. EMBO J 2000; 19: 5324-5331.

38. Ostrander DB, Ernst EG, Lavoie TB, Gorman JA. Polyproline binding is an essential function of human profilin in yeast. Eur J Biochem 1999; 262: 26-35.

39. Ding Z, Gau D, Deasy B, Wells A, Roy P. Both actin and polyproline interactions of profilin-1 are required for migration, invasion and capillary morphogenesis of vascular endothelial cells. Exp Cell Res 2009; 315: 2963-2973.

40. Janke J, Schluter K, Jandrig B, Theile M, Kolble K, Arnold W et al. Suppression of tumorigenicity in breast cancer cells by the microfilament protein profilin 1. J Exp Med 2000; 191: 1675-1686.

41. Yao W, Ji S, Qin Y, Yang J, Xu J, Zhang B et al. Profilin-1 suppresses tumorigenicity in pancreatic cancer through regulation of the SIRT3-HIF1 $\alpha$ axis. Mol Cancer 2014; $13: 187$.

42. Zou L, Jaramillo M, Whaley D, Wells A, Panchapakesa V, Das T et al. Profilin-1 is a negative regulator of mammary carcinoma aggressiveness. Br J Cancer 2007; 97: 1361-1371.

43. Li C, Yu S, Nakamura F, Yin S, Xu J, Petrolla AA et al. Binding of pro-prion to filamin A disrupts cytoskeleton and correlates with poor prognosis in pancreatic cancer. J Clin Invest 2009; 119: 2725-2736.

44. Vousden KH, Lu X. Live or let die: the cell's response to p53. Nat Rev Cancer 2002; 2 594-604.

45. Liu B, Chen Y, St. Clair DK. ROS and p53: A versatile partnership. Free Radic Biol Med 2008; 44: 1529-1535.
46. Lavin MF, Gueven N. The complexity of p53 stabilization and activation. Cell Death Differ 2006; 13: 941-950.

47. Assinder SJ, Stanton JA, Prasad PD. Transgelin: an actin binding protein and tumour suppressor. Int J Biochem Cell Biol 2009; 41: 482-486.

48. Nair RR, Solway J, Boyd DD. Expression cloning identifies transgelin (SM22) as a novel repressor of 92-kDa type IV collagenase (MMP-9) expression. J Biol Chem 2006; 281: 26424-26436.

49. Chunhua L, Donglan L, Xiuqiong F, Lihua Z, Qin F, Yawei L et al. Apigenin up-regulates transgelin and inhibits invasion and migration of colorectal cancer through decreased phosphorylation of AKT. J Nutr Biochem 2013; 24: 1766-1775.

50. Pradines E, Loubet D, Schneider B, Launay JM, Kellermann O, Mouillet-Richard S. CREB-dependent gene regulation by prion protein: impact on MMP-9 and beta-dystroglycan. Cell Signal 2008; 20: 2050-2058.

51. Mannello F, Luchetti F, Falcieri E, Papa S. Multiple roles of matrix metalloproteinases during apoptosis. Apoptosis 2005; 10: 19-24.

52. Tavender TJ, Sheppard AM, Bulleid NJ. Peroxiredoxin IV is an endoplasmic reticulumlocalized enzyme forming oligomeric complexes in human cells. Biochem $\mathrm{J} 2008$; 411 : 191-199.

53. Giguere $P$, Turcotte ME, Hamelin E, Parent A, Brisson J, Laroche G et al. Peroxiredoxin-4 interacts with and regulates the thromboxane $A_{2}$ receptor. FEBS Lett 2007; 581: 3863-3868.

54. Tavender TJ, Bulleid NJ. Peroxiredoxin IV protects cells from oxidative stress by removing $\mathrm{H}_{2} \mathrm{O}_{2}$ produced during disulphide formation. J Cell Sci 2010; 123: 2672-2679.

55. Cusinato F, Pighin I, Luciani S, Trevisi L. Synergisam between staurosporine and drugs inducing endoplasmic reticulum stress. Biochem Pharmacol 2006; 71: 1562-1569.

56. Sarkar S, Floto RA, Berger Z, Imarisio S, Cordenier A, Pasco M et al. Lithium induces autophagy by inhibiting inositol monophosphatase. J Cell Biol 2005; 170: 1101-1111.

57. Mariño G, Niso-Santano M, Baehrecke EH, Kroemer G. Self consumption: the interplay of autophagy and apoptosis. Nat Rev Mol Cell Biol 2014; 15: 81-94.

58. Traba J, Del Arco A, Duchen MR, Szabadkai G, Satrústegui J. SCaMC-1 promotes cancer cell survival by desenzitizing mitochondrial permeability transition via ATP/ADP-mediated matrix Ca(2+) buffering. Cell Death Differ 2012; 19: 650-660.

59. Kruman I, Guo Q, Mattson MP. Calcium and reactive oxygen species mediate staurosporineinduced mitochondrial dysfunction and apoptosis in PC12 cells. J Neurosci Res 1998; 51: 293-308.

60. Christie DA, Lemke CD, Elias IM, Chau LA, Kirchhof MG, Li B et al. Stomatin-like protein 2 binds cardiolipin and regulates mitochondrial biogenesis and function. Mol Cell Biol 2011; 31: 3845-3856.

61. Beard RS Jr, Bearden SE. Vascular complications of cystathionine ß-synthase deficiency: future directions for homocysteine-to-hydrogen sulfide research. Am J Physiol Heart Circ Physiol 2011; 300: H13-H26.

62. Fu M, Zhang W, Wu L, Yang G, Li H, Wang R. Hydrogen sulfide $\left(\mathrm{H}_{2} \mathrm{~S}\right)$ metabolism in mitochondria and its regulatory role in energy production. Proc Natl Acad Sci USA 2012; 109: 2943-2948.

63. d'Emmanuele di Villa Bianca R, Mitidieri E, Esposito D, Donnarumm E, Russo A, Fusco F et al. Human cystathionine-ß-synthase phosphorylation on Ser 227 modulates hydrogen sulfide production in human urothelium. PLoS One 2015; 10: e0136859.

64. Shao J, Welch WJ, DiProspero NA, Diamond MI. Phosphorylation of profilin by ROCK1 regulates polyglutamine aggregation. Mol Cell Biol 2008; 28: 5196-5208.

65. Blum H, Beier H, Gross HJ. Improved silver staining of plant proteins. RNA and DNA in polyacrylamide gels. Electrophoresis 1987; 8: 93-99.

66. Ramljak S, Asif AR, Armstrong VW, Wrede A, Groschup MH, Buschmann A et al. Physiological role of the cellular prion protein $\left(\operatorname{PrP}^{\mathrm{C}}\right)$ : protein profiling study in two cell culture systems. J Proteome Res 2008; 7: 2681-2695.

67. Zafar S, von Ahsen N, Oellerich M, Zerr I, Schulz-Schaeffer WJ, Armstrong VW et al. Proteomics approach to identify the interacting partners of cellular prion protein and characterization of Rab7a interaction in neuronal cells. J Proteome Res 2011; 10: 3123-3135.

(1) Cell Death and Disease is an open-access journal published by Nature Publishing Group. This work is licensed under a Creative Commons Attribution 4.0 International License. The images or other third party material in this article are included in the article's Creative Commons license, unless indicated otherwise in the credit line; if the material is not included under the Creative Commons license, users will need to obtain permission from the license holder to reproduce the material. To view a copy of this license, visit http://creativecommons.org/licenses/by/4.0/

(C) The Author(s) 2017 